\title{
The Ecological Analysis of White Noise by Don DeLillo
}

\author{
Yuxin $\mathrm{Zhao}^{1}$ \\ ${ }^{1}$ Foreign Language School of Harbin University of Science and Technology, Harbin, Heilongjiang, \\ China, 150040 \\ ${ }^{\mathrm{a}}$ email,
}

Keywords: Post-Industrial Era, American Society, Ecological Crisis, Spiritual Ecology

\begin{abstract}
In the post-industrial era, American society has undergone unprecedented development. With industrial civilization, human ability of conquering and transforming the nature is increasing while living environment is deteriorating; people's material life is more prosperous, and so is the consumer culture. On the other hand, more ecological crises appear; under the natural and social ecological imbalance, the spiritual world of humans is facing a huge crisis. White Noise focuses on the industrial civilization, mass media, consumer culture and ideology of the modern living conditions, which affect behaviors, thoughts, feelings and psychological aspects of humans in the post-industrial era in American society, thus showing a deep humanistic concern.
\end{abstract}

\section{Introduction}

White Noise is a masterpiece of contemporary American writer Don DeLillo. The story was shot in the so-called College-on-the -Hill of a small town in the central United States, revolving around the protagonist Professor Jack Gladney and their daily family life. The novel is particularly concerned about natural crises caused by industrial civilization in the post-industrial era, American social crisis, and spiritual confusion of modern people, showing the author's deep ecological concern and strong sense of mission, which is considered to be a masterpiece of ecological literature.

\section{The Industrial Civilization and the Natural Ecological Crisis}

In post-industrial era of American society, industrial civilization has gained unprecedented development in science and technology, which greatly change the world. However, the destruction of natural ecosystems thrives. "The so-called natural ecological crisis refers to the people who involve in production from the outside of the natural ecology, causing destruction in whole or in similar overall and, in turn, constituting a direct threat to human survival." [1] 9

In White Noise, the Gladney family has personally experienced a sudden "Airborne Toxic Event": the accidental leakage of toxic substances cause serious air pollution and the safety of town residents are under threat. After the emergence, the government and relevant departments do not realize the seriousness of the underlying problem, and then find a solution. Instead, they implant certain microbes in the center of smog to devour toxic substances, in order to meet their urgent needs. Although the novel does not further describe whether the event can trigger secondary disasters, the characters in the novel are living in constant panic. Jack's son, a 14-year-old boy begin to bald, so he is worried all day, suspecting that his mother must eat something bad or what might change the genes during pregnancy; or it may be because they happen to live near a chemical waste dump, thus causing his son to grow up in hazardous environments; or the wind drift of industrial exhaust gas may contain a substance to cause baldness. Babette, Jack's wife, is trying to heal her fear of death as well. She learns about a product called " Dylar" from a newspaper ad, in which the scientists claim that it can get rid of people's fear of death. Babette is recruited to become a test volunteer of the effects of the drug.

Of course, the industrial civilization, as well as science and technology, contributes to the transformation of the human world in the process. However, once the technical controllers become 
irrational and irresponsible, and blindly get into the embrace of technology, "the technical rationality, the main weapon of human civilization, can build itself while acting on nature. Both the nature and the whole human race can become victims. "[2]. With human conquest of nature, the planet and humanity itself may be completely destroyed.

\section{The Social Ecological Imbalance}

Post-industrial American society presents material prosperity, social stability and leisurely appearance of people's lives. In White Noise, Professor Jack - Gladney belongs to a typical middle-class family. They have flourishing careers, a sweet marriage, and a harmonious family life. However, for such a seemingly "happy" family, it is difficult to cover up the reality of indifference and a sad reminder. Throughout the entire novel, the relationship between man and man, man and society, and man and self, all shows alienation.

What is the poison in the post-industrial era of American society?

\section{The Mass Media and Consumer Culture}

Post-industrial American society is besieged by the mass media, supermarkets, shopping malls and a variety of images. Advertising is the sudden emergence of the modern doctrine of propaganda consumer. In White Noise, the trio of advertising spots constantly on television; Babette uses storytelling voice to several blind people, reading tabloids and ads; she also finds out Dylar from the newspapers. In addition to the ad appearing in the mass media and the street, ads can be seen everywhere, even in the elevator. Advertising has broken the geographical boundaries and countries. All over the world people can see the Coca-Cola advertising; Jack's daughter Steffie repeats Toyota Celica, a brand name of Japanese cars in a dream. For many people in this era, there are only two places in the world: "where they live and what televisions show them to see." ${ }^{[3]}$ Watching TV is one of the most important activities of Jack's family, his wife even call on the whole family to sit in front of the TV and watch TV together on Friday night, in order to maintain a harmonious and healthy family life.

Post-industrial society in the United States is like a large supermarket, all can be sold and anything can consume. The novel once mentions that a famous farmhouse attracts Jack and Murray. There, tourists are everywhere with cameras, tripods, telephoto lenses and filters and other kinds of equipment. No one "sees" the farmhouse. They are designed to get into this atmosphere, consuming the scene of crowds ${ }^{[4]}$. Academics can also be commercialized. In the novel, Hitler is also packaged into a commodity, whose image appears frequently in the mainstream media like a pop star. Even professor Jack Galdney proposes to the principal of the college and creates a Department of the Ministry of Hitler's life and career as a research object.

\section{White Noise}

In DeLillo's novel, "White Noise" refers to all the inaudible noise-- radio, television, microwave, ultrasound equipment and other issue. White noise of modern civilization is disturbing sounds, and it is a symbol of modern life. Mixed with all kinds of information, simply "it does not leave any space for people who are engaged in spiritual communication and aesthetic thinking ...... (people) do not have the ability to deal with this information; the brain is full of random accumulation, pieces of disorderly information, so that people become negatively encoding the information rather than positive thinking. The information is overloaded and causes anxiety. "[4]. Noise is what people do not want to hear, and do not want to receive. It is the signal that people make an attempt to shield. Modern civilization produces white noise, invading people's fragile brain and making it numb.

"The media repeatedly replicate indefinitely marks and images, and everywhere is permeated with advertising and sign languages. The overproduction of marks and reproduction of images result in a fixed sense of loss." [5]22 Endless bombardment of advertising, flood-like waves and white noise seem to have some kind of corrosive power, so that people lose the ability to distinguish the real and the virtual. The author of the novel patiently describes the daily life of various noises, impetuously and profoundly reveals the emptiness of post-modern society, which reflects a contemporary cancerous human environment" ${ }^{[2]}$, and the people who live under this living environment. 


\section{The Obstacles Language and Communication}

Language and communication is the basis of human relationships.Through the exchange, people build the relationship between self and others, as well as the society. Communication can shorten the distance of loneliness, and build a defense structure of fear in our souls. However, in the post-modern family, family members are relatively independent and lack a common topic, resulting in barriers to communication.

White Noise appears more than once dialogues between Jack and Babette. They often revolves around who will die first, a debated topic in this regard reflecting the limitations of the exchange between the couple. It also implies that in their marriage they both want to disguise the fear of death and spiritual emptiness. After the airborne toxic event, the fear of death lingers in Jack's mind all the time, but he tries to suppress and conceal it. For many modern people, pleasure brought by exchanges is far away from satisfaction in shopping and television. At the end of a desirable and enjoyable home shopping activity, the family quietly drive home, and they all walk into their rooms. Soon after, Jack's daughter Steffie is sitting in front of the TV. ${ }^{[3]}$

The barriers of communication reflects the lack of trust between people. For families, the lack of trust and sense of belonging is mainly attributed to the unstable post-modern family structure. In the novel, Jack has a total number of five marriages and four wives (his fourth marriage is with his first wife). In the fifth marriage, he and Babette have four children. Without a fixed morbid family structure and family atmosphere, the home is no longer a safe, warm heaven. Marriage, divorce and remarriage, and lack of stable marital relationship cause modern family in lasting turmoil. Both children and adults are unable to derive a sense of belonging and shelter from it.

\section{Spiritual Ecology}

In the post-industrial era of American society, deterioration of the natural environment is a serious threat to human biological existence, and social ecological imbalance results in risks of human social existence. With the joint action, human spiritual crisis could be more destructive.

Firstly, Spiritual crisis lies in faith decay. In White Noise, the nuns doesn't believe in God, but they pretend to, because they understand humans need the belief. Only so, can the disorderly and chaotic world have some meaning and order. Perhaps the nuns also need a kind of self-redemption from a disordered, chaotic world. Maybe other people do not really believe that God exists, but they are presuming its existence to cover up the emptiness inside. The so-called "faith" has no relation to a true heart, and "usefulness" will be enough.

Secondly, the popular consumer culture of post-industrial civilization lacks core values and meaning. Therefore, people subconsciously adopt various means to try to shield spiritual emptiness and pain, so feeling relaxed. Among various means, the common ones are watching television and shopping. Diverse TV programs can meet the tastes and needs of different groups, who are eager to kill the time in order to resolve mental anguish; shopping is to let people feel both material wealth and enjoy the satisfaction of possession. As the frequented sites, supermarkets and shopping malls highlights the material affluence of American society in the post-industrial era, as well as resolving people's anguish of spiritual aspects which can not be ignored. People get satisfaction in the shopping process, enriching the spiritual world of emptiness.

\section{Conclusion}

In American society, the material life has reached an unprecedented height, while the living environment is deteriorating sharply. Consumer culture and the mass media exert strong impacts on the modern spiritual world, and therefore the society has become less vibrant. As an author with a strong sense of responsibility, DeLillo is standing at the forefront of the post-industrial era of American society, observing and listening to whatever is going on. Therefore, ecological writing in White Noise is so penetrating and far-reaching. 


\section{Acknowledgements}

Fund Project: The Studies of Don DeLillo from the Ecological Perspective (UNPYSCT-2015049)

\section{References}

[1] Lu Shuyuan. Spiritual Ecology and Ecological Spirit. Southern Press, 2002.9

[2] Zhu Xinfu. Foreign Literature Studies, Vol. 5 (2005) No 27, p.74-76

[3] Don DeLillo. White Noise. Penguin Classics, 2009

[4] Zhang Min. Northwest University, Vol. 29 (2005) No 27, p.21-23

[5] Mike Featherstone. Consumer Culture and Postmodernism. Yilin Press, 2000 